\title{
Viral G-Protein Coupled Receptor
}

National Cancer Institute

\section{Source}

National Cancer Institute. Viral G-Protein Coupled Receptor. NCI Thesaurus. Code

C114505.

Viral G-protein coupled receptor (342 aa, $\sim 39 \mathrm{kDa}$ ) is encoded by the human herpesvirus 8 ORF74 gene. This protein plays a role in the positive regulation of ang iog enesis, cell migration, cell proliferation and cell survival. 